\title{
Arabisation and language use in Algeria
}

\section{Hind A. Mostari}

\section{Introduction}

Algeria got its independence on 5 July, 1962. The Algerian leaders especially the nationalists soon adopted the slogan: "L'islam est notre religion, l'Algérie est notre patrie , la langue Arabe est notre langue." ( Islam is our religion, Algeria is our mother country, Arabic is our language). After independence, Algeria had an urgent need to regain its Arab and Muslim identity. Since Classical Arabic is the language of the Koran throughout the Muslim speaking world and since the language is an instrument of power ( La langue est un instrument de pouvoir ( Hadjara 2000:02), great campaigns of Arabisation were launched in order to replace French, the language of the coloniser with Classical Arabic as the language of Arabo-Islamic identity. For the Algerian elite especially the nationalists, Classical Arabic was the best vehicle of communication and instruction without which Algeria would probably lose its identity and values. Within this framework, President Boumediene (1968) ( quoted in Bouhania, 1998 : 26) declared: "Sans la récupération de cet élément essentiel et important qui est la langue nationale, nos efforts resteront vains, notre personnalité incomplète et notre entité un corps sans âme."( Without recovering that essential and important element which is the national language, our efforts will be vain, our personality incomplete and our entity a body without a soul) This was probably an expected choice. Indeed, the Algerian society whose true identity had been denied for a hundred and thirty two years, could not begin to reconstruct itself without restoring the bedrock of that identity; the Arabic language which remains a vivid symbol of its Arabic identity and Islamic values. The group which was actively promoting the Arabisation process immediately after independence consisted of Algerian nationalists and political leaders who were extremely anxious and eager to find out their place in an overwhelming French speaking country. Hence, the political leaders' first preoccupation was to build the Algerian identity upon two major points which are : Islam and "Arabity". Such goals could not be achieved without an effective language policy. 


\section{The policies of arabisation in Algeria}

Algeria inherited a French linguistic heritage of 132 years and the Arabisation process came to change such a situation. Arabisation as the term is understood in the Maghrebi regions means restoring the Arabic language. Several laws, decrees and ordinances were enacted, reinforced and applied aiming at implementing Classical Arabic and strengthening its position in all public domains. For the Algerian Francophones, the Arabisation policy was a major blow since it reduced the status of French to a foreign language. Hence, the Arabisation process was featured by a long running clash between the defenders or the promoters of Classical Arabic and the advocates of the retention of the French language. The former favoured Classical Arabic regarding it as an integrated and essential component of the Algerian personality. The latter gave priority to development claiming that Classical Arabic is an outdated language which cannot cope with modernity and technology. The Arabisation campaigns were launched in various public domains notably Administration, Environment and Education.

\section{Administration}

Classical Arabic was confronted with the hostility of the French infrastructure inherited after independence. Hence, Algeria faced many socio-cultural and linguistic problems among them the highly illiterate population, a small elite with a French or Arabic background as well as an Arabic language (Classical Arabic) which was imposed as the sole official and national language of the new nation. Within a Frenchified administration, the Algerian officials seemingly did not master Classical Arabic. Therefore, the Algerian government decided to restore Classical Arabic in Administration progressively but quickly. By a 1968 Decree, President Houari Boumediene (1965-1978) attempted to create radical and effective changes in public administration. This decree states: "Dans un délai de trois ans, les fonctionnaires doivent apprendre suffisamment d'arabe pour travailler dans cette langue." (Guillaume $1997: 03$ ) (In a period of three years, functionaries should learn enough Arabic to work in this language.)

This decree imposed Arabisation on the civil service, ordering civil servants to learn enough Arabic to work in the language within three years. Not many of thern managed to do so, but there is no doubt that this measure effectively opened the doors of the civil service to Arabisation. In 1977, a technical committee of Arabisation was set up for the task of providing all the means to realize Arabisation in Administration. More recently, on 17 December 1996, the Algerian Transitional National Council (CNT),voted unanimously to adopt a law on the "Generalization of the Use of the Arabic Language". 
Its main stipulation is that by 5 July 1998 (or the year 2000 in the case of higher education) :

Les administrations publiques, les institutions, les entreprises et les associations quelle que soit leur nature sont tenues d'utiliser la seule langue arabe dans l'ensemble de leurs activités telles que la communication, la gestion administrative, financière, technique et artistique.

All public administrations, institutions, enterprises and associations, of whatever nature, are required to use only the Arabic language in all their activities, including communication and administrative, financial, technical and artistic management.

The act also specifies that "The use of any foreign language in the deliberations and discussions of official meetings is forbidden."

\section{The environment}

The Circular of July 1976 (Articles $3 \& 4$ ) which was concerned with the Arabisation of the Environment states :

Art.3 Arabiser totalement toutes les enseignes extérieures des administrations et sociétés publiques et interdire absolument toute inscription en langue étrangère.

( To Arabise totally all the external and internal signs of public administrations and companies and absolutely forbid any inscription in a foreign language.)

Art.4 Utiliser seulement l'écriture en arabe pour les divers services, bureaux et guichets internes et pour les diverses inscriptions, panneaux d'indication ou d'orientation

( To use only the Arabic script for various services, offices and pay-desks and for diverse inscriptions, indication or orientation panels.)

Therefore, public inscriptions were soon written in Classical Arabic. Interestingly enough, in Algiers (on October 1976), in only one night, all the transcriptions panels were replaced with others written in Classical Arabic. In fact, the real objective was to impose Arabisation on people; to force them, to some extent to read everything, everywhere in Classical Arabic. In other words, to expose people to an environment which is $100 \%$ Arabized, as if the Algerian politicians wanted not only to promote the status of Classical Arabic but also to give to Algeria what Guillaume (1997:03) called 'un visage Arabe' (An Arab Face) 
Hence, avenues and streets' French names were replaced with Arabic ones, for instance, Baudelaire Street in Sidi Bel Abbés town became Sakiet Sidi Youcef Street, the villages'( or town-ships' ) names changed too: for example, Descartes became Mustapha Ben Brahim and Detrie became Sidi Lahcen (these villages are situated in the Sidi Bel Abbés area).

In reality, if public administration principally uses Classical Arabic in its written forms, other structures especially the social ones, use both Classical Arabic and French. In the economic field, some import- export companies use both Classical Arabic and another foreign language ( which can be either French, English or Spanish depending on the country from where the product is imported ), for their product labels and packages, as in the case of pharmaceutical, cosmetic or general consumption products.

Within this framework, Article 21 of the Law no. 91-05 of 1996 states that:

"Sont imprimés en langue Arabe...et en plusieurs langues étrangères...les documents imprimés, emballages et boîtes."

(Are printed in the Arabic language...and in many foreign languages...documents, forms, packages and boxes.)

Despite the tremendous financial and political efforts to Arabise the environment, seemingly many private enterprises prefer using French or English names in their signs more than Classical Arabic. At the social level, this can be explained by the strong European influence upon the Algerian speech community. At the economic level, it seems that customers are more or less attracted by foreign names.

\section{Education}

The educational profile of the Algerian society changed dramatically with the Algerian independence, when most of French and other Europeans left. As the majority of technicians and administrators were Europeans, Algeria was left with a shortage of highly skilled and educated people. In the educational system, the first reform taken immediately after independence, was to teach Classical Arabic starting from the primary level, French became a second language ( 1964) and then a foreign language with the application of the Foundation School system in 1976. In fact, there was a political attempt to reconcile the restoration of the national language, Classical Arabic, without neglecting French which constitutes an essential means in the acquisition of technology and modern sciences. Thus, within the Foundation School System, the restoration 
of Classical Arabic was soon followed by political measures in order to retain French. Within this perspective, President Benbella declared in 1965 that Arabisation campaigns did not mean the elimination of the French language. It should be noted however, that the Arabisation process was not evident and its implementation strategies were not easy to realise in various domains such as in education.

At the beginning of the 1963 school year, the education system was in complete disarray, and enrolments in schools at all levels totalled only 850,000 . In the years immediately following, teachers were trained hastily or recruited abroad ( particularly from the Middle East countries especially from Egypt, Syria and Iraq). Classrooms were improvised, many in the vacated homes of former French residents. Attendance climbed to 1.5 million in 1967, to nearly 3 million by 1975 , and to 6.5 million in 1991-92. In the mid 1970s, the Algerian authorities legislated a number of reforms for the educational system including primary, secondary and university levels. In order to quicken the Arabisation process and realize a total Arabisation from the primary to secondary levels, all teacher training centres were Arabized and no Francophone teachers were trained starting from 1974.

Within the same context of quickening the Arabisation process, the first National Conference on Arabisation was held between 14-17th May 1975, recommending Arabisation in all sectors of life. This Conference gave birth to a Sub-Commission of Training and Teaching which determined a three term progressive Arabisation:

- A short term from 1976 to 1978 during which the rate of Arabized classes in primary and secondary levels would increase from half to one third.

- A mid term from 1976 to 1980 which was concerned with a partial Arabisation in some scientific and technical fields at University.

- A long term period from 1976 to 1982 at the end of which Arabisation should be brought to a successful conclusion from the primary to the secondary levels.

As an efficient step towards Arabisation inside universities, Commissions were set up on 12 October, 1971 in order to elaborate an Arabisation plan. The Arabisation process was gaining ground at the university. Courses in Arabic were held in order to teach terminology to the students of different fields and disciplines. If Arabisation was totally achieved in both primary and secondary levels, This was not the case in universities where Arabisation was :

- Integral in Literature, History and Pedagogy.

- Partial in Geography, Law, Journalism, Sociology and Psychology

- Nil in scientific and technical specialities such as Medicine, Exact Sciences and 
Engineering Departments where French has acquired a position of paramount importance since it became an essential and omnipresent tool of teaching.

Despite the linguists' efforts to modernise Classical Arabic, the latter remains relatively unable to replace French in such Departments which have strongly resisted to the campaigns of Arabisation.

\section{The impact of arabisation in public domains}

One of the most important concerns of Algeria during the post independence era was to restore Classical Arabic as the main medium of interaction, thus, many laws, decrees and ordinances were enacted. However the result was not as intended. In fact, what was planned to be used is one thing and what is practically used is quite another thing. Indeed, the impact of the Arabisation process varied from one field to another ; being efficient in some public domains and non-existent in others.

\section{Administration}

Administration was among the most important public domain where the Arabisation process was particularly intensified. However, after many years of hard work, Arabisation is a qualified failure. Indeed, only the Ministries of Defence, Education and Justice have been Arabized, the other domains are particularly characterised by Arabic / French bilingualism. Consequently, in some public institutions and departments, we may find documents written in Classical Arabic on the right of the forms and in French on the left side, in order to facilitate comprehension such as in the case of Banks ( cheques ), Post Offices ( forms ), and Algerian Airways (airline ticketş).

That is to say that, currently and after 41 years of intensive efforts and optimistic expectations, French is strongly present in the Algerian Administration and its impact is so important that many Algerians from different sociolinguistic and cultural backgrounds, find difficulties in filling in forms or writing official letters in Classical Arabic. What is striking and interesting in this case, is that we notice that many people proudly display or show their inability to understand Classical Arabic, simply because they use French, which is for them the ultimate reflection of modernity and education. Mastering Classical Arabic is not an urgent matter for them because French has proven to be the more useful and prestigious language. 


\section{The environment}

The Arabisation process has been boosted by the enactment and the application of several Ordinances, Presidential Decrees and Laws such as the 1976 Law of Arabisation followed by the Presidential Decrees of March 1981 and 1982. In the latter, bilingualism was allowed in the environment, ie. the use of both Classical Arabic and French printed in public inscriptions for practical reasons among them: to enable foreigners or even some Algerians who could not read Classical Arabic to read them in French. Although the Arabisation process was particularly intense in the environment as witnessed by a large number of panels, signs, avenue and road names in Classical Arabic, it seems that their old French names are still stuck in people's minds even among the new generation. For instance, when young people want to reach a place, they often give to the taxi driver its old French name.

\section{The mass media}

In this section, we shall discuss the main channels or means of communication that reach a large number of people, it includes the radio, television and newspapers.

\section{The radio}

Many radio channels exist in Algeria, they are supervised by the Ministry of Information and Culture which has a monopoly on radio and television broadcasting in the country. The national networks cover the entire country with three channels : Arabic, French and Berber.

Among the radio stations which broadcast in Arabic, we have Alger Chaîne I. Although news and the majority of the programs are presented in Classical Arabic, it is noticed that both French and Algerian Arabic may be used especially in programs where there is a direct interaction between the presenter and his/her guests, or between the presenter and his/her listeners especially when the latter phone in to sing along or participate in games or when they give their opinions about particular subjects or problems which are brought up in the program.

Among the radio channels which broadcast in French, we have Alger Chaîne III and in Berber ; Chaîne II and Mitidja FM. In addition to these channels, there are regional ones such as El Bahia FM, El Bahdja in Oran and Bechar Essaoura in Bechar.

The existence of more than one channel broadcasting in different languages certainly reflects not only the linguistic diversity of the speakers but also their will to express 
themselves in other languages than Classical Arabic. In this regard, Guillaume (1997:04) asserts: "La société Algérienne est pluraliste dans ses régions et dans ses langues." ( The Algerian society is pluralist in its regions and in its languages.)

\section{Television}

In Algeria, there are two television channels; The National Enterprise of Television (ENTV: Entreprise National de Television), one national and the other international mostly addressed to Algerian immigrants in Europe. These channels are run by the Ministry of Information and Communication.

The Algerian television presents different programmes dealing with education. religion, games, economy and so on, which are mostly given in Classical Arabic.

Since Classical Arabic is supposed to be the only language of communication on television, it is noticed that in some television interviews, journalists or presenters ask speakers to answer in Classical Arabic. In some cases, the journalists translate the speaker's speech from Algerian Arabic to Classical Arabic.

There is no doubt that speaking only Classical Arabic on Television is difficult not only for ordinary people but also for the fervent advocates Arabisation, as Hadjarab (2000:2 ) confirms :

"Cela donne des situations absurdes. Des hommes politiques... qui s'expriment très mal en arabe classique baragouinent et cherchent désespérément leurs mots classiques à la télévision au lieu de parler la langue du peuple."

(This leads to absurd situations. Politicians ... who badly express themselves in Classical Arabic jabber and desperately look for their classical words on television instead of speaking the language of the people.)

As far as Algerian films and television series are concerned, we can divide them into three types:

- Films where actors exclusively use Classical Arabic as it is in the case of historical films or television series dealing with, for instance, Islamic issues or Arabic literature.

- Films or television series where actors can use Algerian Arabic, Classical Arabic and French, which are a mere reflection of the real linguistic reality of the Algerian speech community.

- Films where the actors are obliged to use mostly Classical Arabic and a little Algerian Arabic. In this case, the majority of the actors' speech is translated to Classical Arabic which makes the screenplay somehow 'unreal'. 
Within this framework, the great Algerian actor Hassan El Hassani (1979) said: “ça m'est arrivé de refuser de jouer dans des films parcequ'on me demandé de dire 'na :fida' au lieu de 'tQ:qa'." ( It happened to me to refuse to play in films because I was asked to say ' window' (in Classical Arabic) instead of 'window' in (Algerian Arabic)."

\section{Newspapers}

Newspapers in Algeria appear mainly in two languages: Classical Arabic and French. There are two types of newspapers; national and regional editions which may appear daily or weekly. Among the national newspapers edited in Classical Arabic, we find: Al dZumhu:rijja (The Republic), al xabar (The News), aSSaxb (The People) El Watan (The Nation), and other newspapers. Among the national Newspapers which appear in French are : Liberté (Liberty), Le Matin (The morning), Le Monde (The World), L'Expression (the Expression), etc.

\section{Education}

One of the most important concerns of Algeria during the post independence era was to restore Classical Arabic as the main medium of teaching in all disciplines. Hence, political authorities expressed a great will and motivation to extend the use of Classical Arabic and if possible to reduce the use of French in education. Thus, various campaigns of Arabisation were launched at different educational levels from the primary to the university levels, aiming at promoting the status of Classical Arabic and correcting the faults of the educational system under colonialism.

Despite the great political efforts and the huge financial means (more than $40 \%$ of the national budget devoted to education) to improve the state of the educational system in Algeria, it seems that education is currently suffering from the lack of a real policy which would take into account the sociolinguistic and cultural environment of the students. Thus, a serious examination and analysis of such factors may help to elaborate efficient pedagogical programmes. For the time being, the state of education is quite deplorable as Guillaume (1997:08) states : "L'école Algérienne se porte mal." (The Algerian school is in bad health.)

The deplorable situation of education in Algeria today, is probably the result of the accumulation of several political and sociolinguistic factors among them the Arabisation process. Indeed, the Arabisation of education was the outcome of an authoritarian decision taken with no consultation, no plan and no method. It was started in the educational system and has spread to all stages of primary and secondary schooling. In 
higher education, the social sciences and humanities have been taught in Arabic since 1980 , the other disciplines are variously affected. Carried out in an authoritarian way, Arabisation has seriously affected the education system's capacity to acquire the scientific and technical knowledge needed for any improvement. Teachers and researchers who have always worked in French have had to revise their knowledge of Classical Arabic, in order to keep their jobs. In 1978 a report by the Algerian National Ministry of Education deplored the increasing marginalisation of scientific and technical education "which was taught in French and was jeopardised with teachers being marginalised or underutilised." (Algerian National Ministry of Education Report 1978:12).

\section{Arabisation and the Berbers' linguistic rights}

In Algeria, the Amazigh or Berber population represents around $20-25 \%$ of the Algerian population. Berber has several dialects among them: Chaouia Tamazight, Taznatit, Kabyle, and others. Kabylians are the most important group which is found in the north west of the country. There are also Shawiya in the Aures Mountains, Mozabites in the Mzab and the Tuaregs in the Ahaggar and Ajjer regions. Thus about 6 - 7 million (in 1997) of Algerians speak one of the varieties of Berber.

Immediately after independence, as already point out, the successive Algerian governments took the task of reviving Classical Arabic and establishing it as the national language. The aim was to recover the pre-colonial past and eventually to restore a national identity and the Arab Muslim personality of the newly freed nation. Such a policy of Classical Arabic implementation was supported by a vast majority of Algerians. Nevertheless, since the Arabisation project does not consider the Berber language as an integral part of it, the Berbers especially the Kabylians have intensified their efforts to slow down if not to halt the Arabisation campaigns.

During the 1970 s and in the attempt to Arabise the registry office, it was forbidden to give Berber names to new-borns. Interestingly enough, in June 1976 the publication of the periodical Fichier Bérbere ( Berber File) was suspended by the Algerian authorities. This periodical was published by French missionaries and was concerned with the Berber culture and history.

Antagonistic sentiments between Berbers and the Algerian government have become explosive since then. The main instruments to reach their goals have been political protests, massive demonstrations and general strikes. Compared with the 1960s and 
1970s protests, the number of demonstrations have remarkably increased since 1991. Indeed, when on 5 July, 1991, a controversial law came into force making Classical Arabic the only language to be used in official documents and other areas of public life fury exploded in the Berber speaking regions and the Berber anger swiftly turned against the State and its Arabisation policy.

In this context, Guillaume (1996:11 ) observed: “Pour les Berbères, cette loi “ scélérate' a pour but non seulement d'accélérer et d'intensifier le processus d'arabisation mais surtout de supprimer définitivement le berbère." (For the Berbers, this " scoundrel ' law aims at not only accelerating and intensifying the Arabisation process but also at suppressing definitely Berber. )

On 3 October 2001, a government statement announced that the Constitution will be amended to make Tamazight a national language. More recently, on 8 April 2002, the Algerian Parliament, unanimously voted (484 against 2) a law which recognises Tamazight as a national language. This is, of course, news of prime importance. However, in the current situation it raises serveral questions such as :

- What form will this constitutional amendment take?

- What space will there be for Tamazight?

- What uses will it have as a national language alongside Classical Arabic, the national and official language?

In announcing that the Berber language is to become a national language under the Constitution, the authorities run the risk of favouring the status of Berbers especially Kabylians ( about $30 \%$ of the population ) over the rest of the population which would probably imitate the Berbers and undertake similar action to get recognition for their local dialects.

\section{Arabisation and the factional struggles}

The enactment and application of many laws concerned with the Arabisation process created stormy debates and generated great struggles at the political as well as the sociolinguistic levels. In fact, from the first time the Algerian politicians decided to launch the Arabisation process, different types of clashes emerged and some of them witnessed great crises and difficult turning points.

Probably, the common conflict which exists is the constant clash between the Arabo- 
phones and the Francophones. In fact, for the Arabophones, Arabisation did not offer them advantages or at least equal chances of social and intellectual mobility with the Francophones. The latter consider Arabisation campaigns as a real linguistic threat which would influence their political and sociolinguistic position in the country. A further struggle which resulted right after the launching of the Arabisation campaigns is the competition between Classical Arabic and French. This is true in the sense that Arabic, as the national and official language, is to replace French. But Arabisation is also presented as a conflict with France, and even those Algerians who use French in their working or private lives are denounced as Hizb Fransa (Members of the "Party of France").

The Arabic language is linked to the two sources of legitimacy on which the government draws: the struggle for national liberation and the defence of Islam. From this point of view, Arabic was the national language and French that of the colonists. The endless repetition of this argument has effectively tarred the Francophone classes, who had a virtual monopoly of power, so to assuage this guilt by associations they co-operated readily with Arabisation measures.

During the presidency of Chadli Bendjedid (1979-1991), the State was plunged into factional struggles. In fact when the Arabisation of higher education was pursued through the $1980 \mathrm{~s}$, Berber movements fiercely opposed to the process appeared on the scene, especially after the government banned a prominent writer to lecture on the history of Berber poetry. In addition to the conflicts which emerged between the advocates of Classical Arabic and Francophones, and between the nationalists and Berber activists, there was another split; the rift between Classical Arabic and people's spoken mother tongues including Algerian Arabic (with its regional variations ) and Berber. Thus, the defenders of Classical Arabic who wanted to see the total linguistic unification of their country, showed great hostility towards the Arabic dialects, which they considered as degenerate forms of pure Classical Arabic. Hence, to confuse the situation, the ideologues of Arabisation declared, for instance, that ' written Arabic' is the mother-tongue since it is "the ancestral language". Educational directives have been issued ordering this written language to be taught as a spoken one. Arabic dialects are seen in Algeria as 'incorrect' forms, faults that teaching ought to correct, if necessary by accusing the pupil or even the adult citizen of unworthy behaviour. Thus, the Algerian speaker, once called a bougnoule (wog) by the French colonists, is now termed an 'uncivilised savage' by his own rulers. Yet Arabisation was supposed to restore his cultural dignity 


\section{Some criticisms of arabisation}

Arabisation faced many criticisms among them the inability of Classical Arabic to cope with technology and modernity, that is why Arabisation partially failed in the technical, scientific and economic fields.

Probably, the major obstacle to the development and promotion of Classical Arabic squarely lies within the great gap between political decisions and execution. Indeed, Arabisation as a goal is one thing, and its implementation in a society is quite another.

The policy of Arabisation evolved in a hostile sociolinguistic environment and Classical Arabic which is the object of Arabisation comes into conflict with other languages especially French; the language of modernity, science and technology.

It should be noted that any political project related to language implementation in public domains should be proceeded by a serious and pragmatic investigation ; a study that would take into account the socio-cultural and linguistic environment in which language is in use. This would probably guarantee a safe point of departure and avoid the irreversible consequences of taking wrong decisions. In terms of language planning, such a study or investigation would have taken into consideration the state of Classical Arabic, its communicative potential, the domains in which it could be implemented and the consequences or the results of language restoration in particular domains. Although the project of Arabisation was politically motivated, it seems that it was also deprived of human and sometimes material supports.

In education, Arabisation has never gone out of the limits of school, it has been applied in fields which do not have a great impact on the extra school environment. Thus, the family circle remains hostile to Arabisation. In addition, pre-schooling and postschooling are not organised to sustain, in the long run, the school action to influence and favour the environment for Arabisation and the expansion of Classical Arabic. In Education, a revision of the set policies must be conducted, a revision of the educational system as part and parcel of the social environment, which is influencing it and being influenced by it, should be the objective pursued.

The linguistic policy pursued by Algerian politicians has always been dictated primarily by political objectives. But aside from these imperatives, the authorities showed no interest in the educational side and no great desire to give Arabic (Classical Arabic) its true value by encouraging historical research and reflection of the Algerian identity. 
Arabisation has been politically not sociolinguistically conceived. It has deviated from its aspects as a socio-cultural project. Language being after all a crucial means of socialisation and intellectual pursuit. Arabisation faced other criticisms among them its inability to cope with other languages which exist in Algeria and its will to fiercely impose Classical Arabic as the sole medium of communication in the unified country.

\section{Conclusion}

There is no doubt that the decision to promote Classical Arabic as the official and national language stems from the role it plays as a unifying agent of the Algerian community within the geographical and religious space. Nevertheless, it seems that such a policy has partly failed in reaching its aims; at the oral level, its impact was almost nil since the Algerian speakers are basically Algerian Arabic/ French bilinguals. At the written level, such a policy has partly succeeded in some institutions and failed in other domains. It was more or less a quantitative success than a qualitative one .

What seems nowadays urgent and crucial is to look at Algeria's pluralism or diversity as a kind of linguistic richness that should be respected, preserved and exploited rather than ignored or eradicated. Nevertheless, the new Arabisation Law does not go in that direction. While the essential task is to forge a consensus around the acceptance of pluralism, official linguistic policy proceeds by constraint and exclusion. On one level, it is forcing a language on people when the sensible thing to do is to persuade them to love it. On another level, it is again undermining the languages people actually speak, Berber in particular, but also French. Arabisation, to put it bluntly, tends to exclude every language except one - the one spoken by the authorities and no-one else. The periodic repetition of these radical measures demonstrates their ineffectiveness. But is the failure to make Arabisation "total" any more shocking than the fact that, for a large part of the population, it has come to symbolise waste, mess and educational failure?

And this is the real scandal that in a universe of languages which reflect so deeply the plurality of the Algerian society, the authorities do not strive to create this space of tolerance, openness and respect of differences.

The reality is that the Algerian society is pluralist: in its regions, its languages, its attitudes to the past and the future, and its view of the West and the Arab world. So far, this diversity has never been properly acknowledged in the context of a general will to live with one another. That is because the country's unity has not been perceived clearly enough at the top. In the absence of a "symbolic enclave of government" which, like 
the keystone of an arch, would hold the entire edifice together, each individual element not only feels threatened, but is seen by the others as a threat to unity.

Probably, the only way to get out of the present sociolinguistic and political crisis is through the establishment of a consensus on this central issue, in which the rule of law would be recognised and the government could at least be seen as the guarantor of society's 'genuine pluralism'. 


\section{References}

Akila, B. 2001. Plurilingualism au Maghreb. In Recueil des Législations linguistiques dans le Monde. Québec : les Presses de l'Université Laval.

Bentahila and Davies. 1983. The syntax of Arabic - French code switching. Lingua.pp 301-329.

Bouamrane, A. 1986. Aspects of the sociolinguistic situation in Algeria. Unpublished PhD Thesis. University of Aberdeen.

Bouhania, B. 1999. The substitution of French loan words for Arabic counterparts in Oran Arabic : a Case Study - Unpublished Magister Thesis. Oran University of Arts and Letters.

Ferguson, C.A. 1959. Diglossia in Language Structure and Language Use. Stanford: Stanford University Press.

Freeman, A. 1996. Andrew Freeman's perspectives on Arabic diglossia. TESL Internet Journal - Vol.2, October.

Grime, F.B. 1996. Algeria, Part of the Ethnologue. Summer Institute of linguistics. London. 13th Edition, pp 1-4.

Gordon, E. 1998. Raids on the articulate: code switching, style shifting and post Colonial writing journal of Commonwealth Literature, 1, 1-24.

Guillaume, G. 1983. Arabisation et Politique Linguistique au Maghreb. Paris : Editions G-P Maisonneuve et Larose.

Hadjarab, M. 2000. L'Algérie au Péril de l'Arabisation. In Lettres sur la Loi de la Généralisation de l'Arabisation. Paris.

Human Development Report of 2001- a Case Study :Algeria : A vulnerable population Hymes, D. 1964. Towards Ethnographies of Communication: the Analysis of Communicative Events. In Paolo Giglioli ed. Language and Social Context. Penguin: Harmondworth.

Shiffman, H.F. 1999. Diglossia as a Sociolinguistic Situation. Temple: Pennsylvania University Press.

Romaine, S. 1989. Bilingualism. London: TJ Press Padstow Ltd.

Wilmsen, D. 1996. Code Switching, Code Mixing and Borrowing in the Spoken Arabic of a Theatrical Community in Cairo. Mushira Eid Editions \& Dilworth Parkinson.

07, Rue Sakiet Sidi Youcef

Sidi Bel Abbes 22000

Algeria

hmostari@yahoo.com 